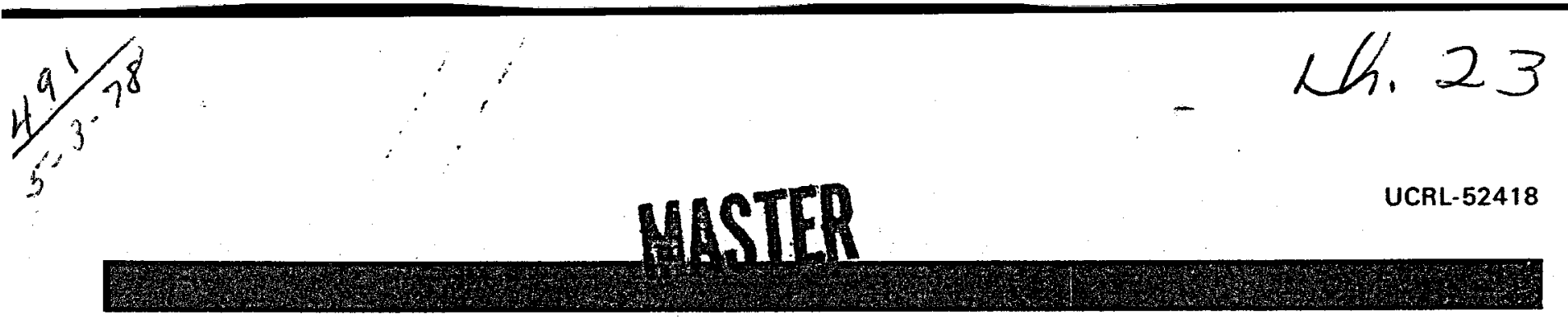

\title{
AN ENVIRONMENTAL GEOLOGY WORKSHOP FOR THE GEYSERS-CALISTOGA KNOWN GEOTHERMAL RESOURCES AREA
}

Gene Ledbetter

Neil B. Crow

February 8, 1978

Work performed under the auspices of the U.S. Department of Energy by the UCLLL under contract number W-7405-ENG-48.

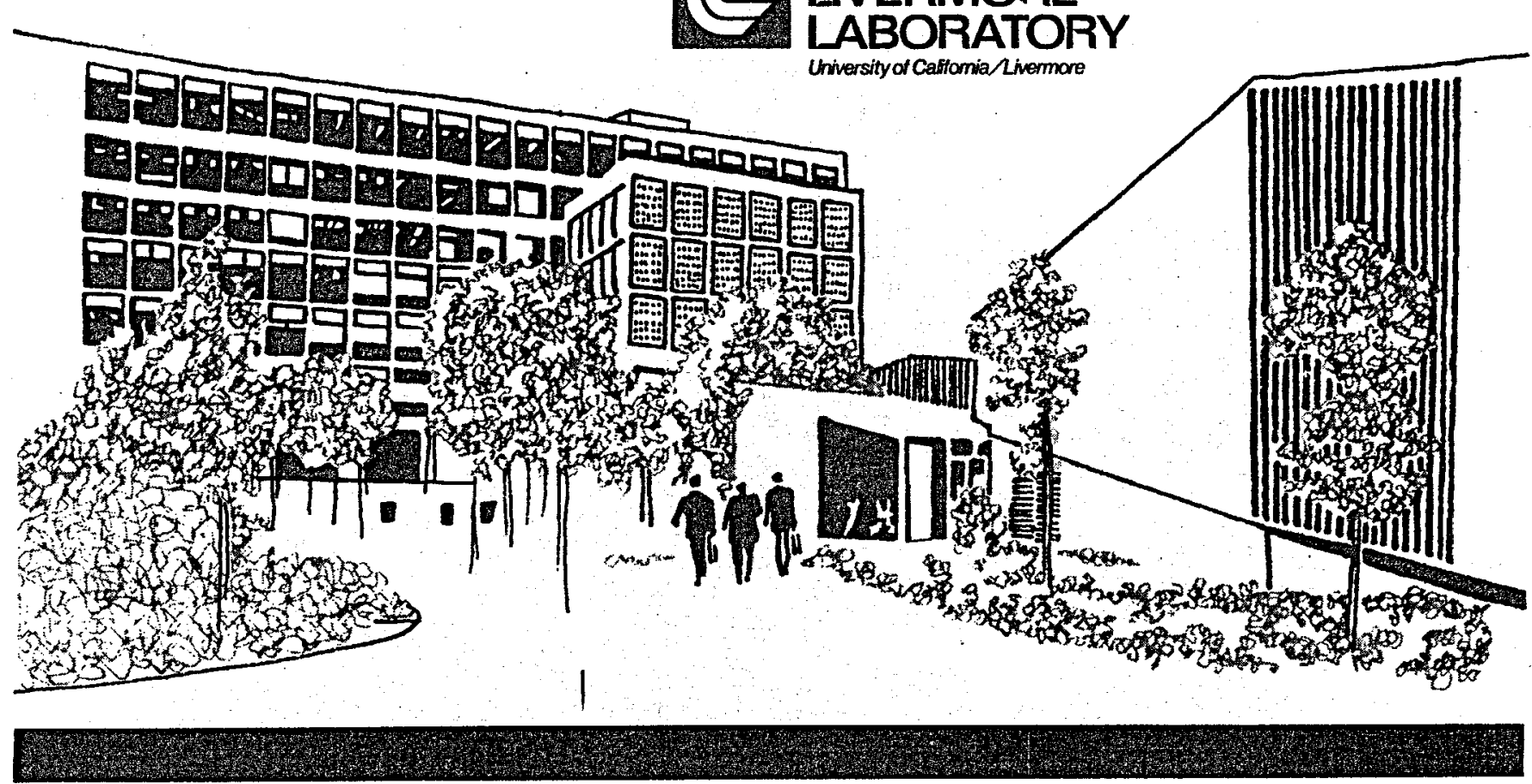




\section{DISCLAIMER}

This report was prepared as an account of work sponsored by an agency of the United States Government. Neither the United States Government nor any agency Thereof, nor any of their employees, makes any warranty, express or implied, or assumes any legal liability or responsibility for the accuracy, completeness, or usefulness of any information, apparatus, product, or process disclosed, or represents that its use would not infringe privately owned rights. Reference herein to any specific commercial product, process, or service by trade name, trademark, manufacturer, or otherwise does not necessarily constitute or imply its endorsement, recommendation, or favoring by the United States Government or any agency thereof. The views and opinions of authors expressed herein do not necessarily state or reflect those of the United States Government or any agency thereof. 


\section{DISCLAIMER}

Portions of this document may be illegible in electronic image products. Images are produced from the best available original document. 


\section{NOTICE}

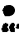

"This report was prepared as an account of work aponsored by the United States Government. Neither the United States nor the United States Department of Energy, nor any of their employees, nor eny of their contractors, subcontractors, or their employees, makes any warranty. express or implied, or assumes any legal tiability or responsibility for the sccuracy, completeness or usefulness of any information, apparatus, product or process disclosed, or represents that its use would not infringe privately-owned rights."

NOTICE

Reference to a company or product name does not imply approval or recommendation of the product by the University of California or the U.S. Department of Energy to the exclusion of others that may be suitable.

Printed in the United States of America Available from

National Technical Information Service

U.S. Department of Commerce

5285 Port Royal Road

Springfield, VA 22161

Price: Printed Copy \$ ; Microfiche $\$ \mathbf{\$ 3 . 0 0}$

\begin{tabular}{ccccc} 
Page Range & $\begin{array}{c}\text { Domestic } \\
\text { Price }\end{array}$ & $\frac{\text { Page Range }}{3}$ & $\begin{array}{c}\text { Domestic } \\
\text { Price }\end{array}$ \\
\cline { 4 - 5 } $001-025$ & 54.00 & $326-350$ & 512.00 \\
$026-050$ & 4.50 & $351-375$ & 12.50 \\
$051-075$ & 5.25 & $376-400$ & 13.00 \\
$076-100$ & 6.00 & $401-425$ & 13.25 \\
$101-125$ & 6.50 & $426-450$ & 14.00 \\
$126-150$ & 7.25 & $451-475$ & 14.50 \\
$151-175$ & 8.00 & $476-500$ & 15.00 \\
$176-200$ & 9.00 & $501-525$ & 15.25 \\
$201-225$ & 9.25 & $526-550$ & 15.50 \\
$226-250$ & 9.50 & $551-575$ & 16.25 \\
$251-275$ & 10.75 & $576-600$ & 16.50 \\
$276-300$ & 11.00 & $601-4 p$ & 1 \\
$301-325$ & 11.75 & &
\end{tabular}

1 Add $\$ 2.50$ for each addittonal 100 vage increment from 601 pages up. 


\title{
14 \\ LAWRENCE LNERMORE LABORATORY \\ University of Calfornia/Livermore, Calfornia/94550
}

UCRL-52418

\section{AN ENVIRONMENTAL GEOLOGY WORKSHOP FOR THE GEYSERS-CALISTOGA KNOWN GEOTHERMAL RESOURCES AREA}

\author{
Gene Ledbetter \\ Neil B. Crow
}

MS. date: February 8, 1978

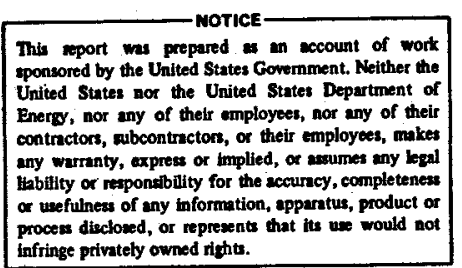




\section{CONTENTS}

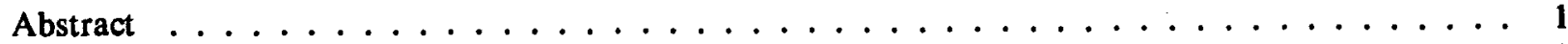

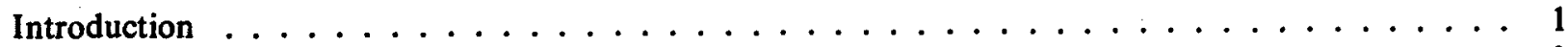

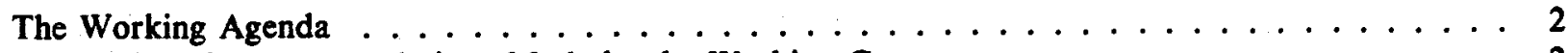

Summaries of Recommendations Made by the Working Groups $\ldots \ldots \ldots \ldots \ldots$

Appendix A: Recommendations Made by the Working Groups . . . . . . . . . . . . . . 4

Geological Mapping Group . . . . . . . . . . . . . . . . . . 4

Slope Stability and Geologic Hazards Group . . . . . . . . . . . . . . 5

Subsidence and Seismicity Group $\ldots \ldots \ldots \ldots \ldots$

Groundwater Hydrology Group . . . . . . . . . . . . . . . . . 6

Appendix B: List of Workshop Attendees $\ldots \ldots \ldots \ldots \ldots \ldots \ldots \ldots$ 


\title{
AN ENVIRONMENTAL GEOLOGY WORKSHOP FOR THE GEYSERS-CALISTOGA KNOWN GEOTHERMAL RESOURCES AREA
}

\begin{abstract}
At the request of the U.S. Department of Energy, Lawrence Livermore Laboratory (LLL) is studying ways in which the environmental quality of The Geysers-Calistoga known geothermal resources area may be protected from any significant harmful consequences of future geothermal development. The LLL study includes the effects of development on air and water quality, geology, the ecosystem, socioeconomics, and noise. The Geothermal Resource Impact Projection Study (GRIPS) has grants to undertake similar work. On 28 and 29 November 1977, LLL and GRIPS jointly sponsored a workshop at Sonoma State College at which knowledgeable earth scientists presented their views on the potential geological hazards of geothermal development. The workshop produced recommendations for studies in geological mapping, slope stability, subsidence, seismicity, and groundwater hydrology. These recommendations will be evaluated along with other considerations and in conjunction with the other subjects of the LLL study. The results of the study will be contained in a preplanning report of final recommendations to the Department of Energy.
\end{abstract}

\section{INTRODUCTION}

A workshop held at Sonoma State College in Rohnert Park, California, on 28 and 29 November 1977 considered ways in which the environmental quality of The Geysers-Calistoga known geothermal resources area (KGRA) north of San Francisco might be protected from potential geological hazards during future geothermal development.

The Geysers first began producing electric power in 1960. It is the only place in the United States where a geothermal resource is producing electricity in commercial quantity, and it is the largest producer of such energy in the world. As commercial development of this valuable resource continues, possible significant adverse effects on the natural environment must be considered. Consequently, the Department of Energy (DOE) has financed a study by LLL to propose ways in which the environmental quality of The Geysers-Calistoga KGRA might be protected. At the completion of its study, LLL will present its recommendations in a preplanning report to DOE. DOE will use this report as a guide in planning environmental studies and research and development projects in The Geysers-Calistoga area.

The LLL study will cover changes in air and water quality, geology, the ecosystem, socioeconomics, and noise that may result from further development of the geothermal field. These topics also concern another organization, the Geothermal Resource Impact Projection Study (GRIPS), which is sponsored by the governments of Lake, Mendocino, Napa, and Sonoma Counties. GRIPS is developing information for interested agencies to use in policy-planning assessments of the environmental impact of geothermal development.

LLL and GRIPS agreed to jointly sponsor a workshop at which earth scientists knowledgeable in the subject could express their views on geological effects of geothermal development at The Geyser-Calistoga field. The workshop was divided into four working groups: geologic mapping, slope stability and geologic hazards, subsidence and seismicity, and groundwater hydrology. At the conclusion of the workshop, each working group presented a list of recommended studies. These recommendations will be evaluated together with other important considerations during the LLL study, and they will influence the final recommendations submitted to DOE in the preplanning report. 


\section{THE WORKSHOP AGENDA}

The first morning of the workshop was devoted to a general meeting of all participants. Cochairmen Neil Crow and Mark Walters discussed the objectives of their respective organizations, LLL and GRIPS, and explained how the workshop had been designed to contribute toward those objectives. For the remainder of the morning, three experts in the geology of The Geysers-Calistoga KGRA's gave talks on important aspects of the local geology.

Robert McLaughlin of the U.S. Geological Survey (USGS) spoke on "Geology and Tectonics of The Geysers/Clear Lake Area: Implications to Environmental Geology," in which he described the very complex geology of the region, which is believed to have been created by the subduction of plates beneath the North American Plate and which is marked by a complex system of faults. He noted that subduction was the probable cause for the introduction of magma from the mantle into the crust below the geothermal area. He also mentioned unstable slope conditions, hydrothermal alteration, and acid leaching as important siting considerations for geothermal development.

In her discussion of "Clear Lake Volcanics," Julie Donnelly of the USGS described the mapping of approximately 100 volcanic units composed of dacite, basalt, andesite, and rhyolite that lie in the portion of the KGRA northeast of the Collayomi fault, which, geochemical studies indicate, may contain hot-water reservoirs. The Clear Lake Volcanic Field is of late Pliocene to Holocene age, and its units are generally progressively younger toward the north.

The last speaker, Trinda Bedrossian of the California Division of Mines and Geology, spoke on "Features of Stable and Unstable Terrain in Parts of The Geysers Geothermal Resource Area Underlain by Franciscan Rocks." She discussed the general slope instability inherent in the Franciscan rocks due to steepness of slopes, chemical alteration, weakness from faulting and shearing, and volume changes in wet clay. She also suggested ways in which geothermal wells could be sited to minimize the danger of blowouts resulting from slope movement.

The first afternoon, participants assembled in four working groups, where the essential business of the workshop was conducted. The groups and their leaders were

- Geologic mapping Robert McLaughlin (USGS)

Forrest Bacon (California Division of Mines and Geology)

- Slope stability and geologic hazards James Vantine (Union Oil)

- Subsidence and seismicity

Ben Lofgren (USGS)

- Groundwater hydrology

Fraser Goff (Rockwell Richland Operations).

Within the bounds of its technical specialty, each group tried to determine the amount and quality of information available for assessing the environmental effects of development. At the end of the first day, the participants reconvened in a general meeting where each group leader presented the conclusions reached by his group.

The second morning, the workshop participants again met in the four working groups. For its particular area of responsibility, each group attempted to determine what was required for environmental assessment of geothermal development. The groups also attempted to identify gaps in existing information and to suggest ways of obtaining it. In the afternoon all the participants reassembled in a general meeting, and the group leaders presented final statements of the conclusions reached by their groups. These are summarized briefly in the next section and stated more fully in Appendix A.

\section{SUMMARIES OF RECOMMENDATIONS MADE BY THE WORKING GROUPS}

\section{Geological Mapping Group}

The Geologic Mapping Group discussed the maps and photographs of the KGRA currently available, their completeness, and their suitability for environmental studies. The group recommended that an index be made of all existing aerial photography and remote sensing records. It noted the need for further mapping at several critical locations where there are small landslides, faults, hydrothermally altered zones, and gaps in the geologic maps. It also urged that all maps and 
related materials be gathered and made available at one location.

\section{Slope Stability and Geologic Hazards Group}

The group decided that a landslide map at a scale of 1:12,000 is the most urgent need in their area of concern. It also recommended an erosion map, a high-resolution regional seismic monitoring net, and a centralized data bank.

\section{Subsidence and Seismicity Group}

This group made several recommendations for studying subsidence: extending the existing geodetic network into areas where future geothermal development is probable, monitoring for changes in tilt and fault offsets, and establishing a data bank for fluid production and reservoir information. In seismic work, the group recommended that the existing dense seismic network at The Geysers be maintained, that the sparse regional network be extended to the north and east, and that networks of digital seismographs in the production area and networks of roving portable seismographs be established.

\section{Groundwater Hydrology Group}

There is insufficient information available to understand the groundwater systems at The Geysers. Therefore, the group made the following recommendations: gathering water-quality data, studying the data and the results of previous investigations to develop an understanding of the groundwater system, and extending the study to include the hydrology of probable areas of future development. 


\section{APPENDIX A: RECOMMENDATIONS MADE BY THE WORKING GROUPS}

\section{Geological Mapping Group}

The area of concern covers approximately $2000 \mathrm{mi}^{2}\left(5200 \mathrm{~km}^{2}\right)$.

\section{Scale of Mapping}

The best scale for planning is $1: 24,000$, but $1: 62,500$ is also useful. The best scale for sitespecific studies varies from 1 in. $=100 \mathrm{ft}$ to 1 in. $=$ $500 \mathrm{ft}$, depending on use. Sonoma and Lake Counties have suitable maps.

\section{Aerial Photography/Remote Sensing}

An index of available material would be useful. There are no critical gaps in the material, but proprietary release may pose a problem at detailed scales. A wide variety of material is available: various types, dates, and scales (especially 1:12,000 or less).

Useful types include color, false color, black-andwhite low sun angle, infrared, satellite and U-2 photography, and side-looking radar (SLR). SLR photographs are available for the entire Geysers area, and VTN and Cartwright photographs are available for most of the area of interest. The county tax departments have maps of each county at $1: 24,000$.

\section{Slope Stability}

Slope stability problems are related to the geologic units. The Clear Lake volcanics pose fewer problems in this respect than the Franciscan rocks. Mapping of the Clear Lake volcanics is essentially complete. The preliminary geologic map and cross section of the Clear Lake volcanic field, USGS open-file map 76-751, by Hearn, Donnelly, and Goff, will be available in six months. The California Division of Mines and Geology has mapped all of Sonoma County. When published, the mapping will be available as an open file report, SR-120.

Robert McLaughlin will map the area toward Wilbur hot springs and around the periphery of the volcanics. Other areas that need to be mapped are the Saint Helena, Calistoga, and Lower Lake quads; southeast of the Clear Lake volcanics; southeast of the Lower Lake quad; and northeast of Coyote Valley.

\section{Heat Flow}

There is little hope of obtaining proprietary heatflow data, and most of the data is proprietary.
Spring water chemistry can provide some information; Julie Donnelly of the USGS expects this data to be released within a year. All water samples in the volcanic areas are mixtures of cold surface water and hot underground water.

\section{Critical Areas to Be Mapped}

- Wilbur Springs

- South of Anderson Springs, near the Collayomi fault

- Island of volcanics, south of Clear Lake

- The Manhattan mine/Grizzly Peak area

- The Harbin Springs/Barceloux Ranch area, near mapping by Robert McLaughlin

- Cache formation

- Tyler Valley/Cloverdale Peak area, extending mapping by Robert McLaughlin

- Witter Springs area

- Gaps in the mapping from north of Boggs Lake to the Highland Springs area

Types of Maps Required

- Small and landslide areas

- Gaps in geologic mapping

- Soil maps. These are available for Sonoma County, and they will be available for Lake County in 1979. The coverage of Napa and Mendocino Counties is unknown.

- Active or potentially active faults (Collayomi, Konocti, and Maacama fault zones)

- Hydrothermally altered zones

- Geophysical maps (gravity, magnetic, spontaneous potential, resistivity, magnetotelluric, seismic, sound)

- Lease maps (for planning). The counties have some of these. It is not necessary to identify leaseholders. These maps would be used to identify areas of future development.

- Hematite zone map

\section{Cost Estimates}

- Cost of mapping: \$250/person/day, plus expenses for consultant. Site-specific maps are paid for by the developer.

- Cost of Air Photography: \$5-10/photograph. Black and white is the least expensive; false color is the most expensive. Government black and white photographs are available for $\$ 3$ apiece.

- Side-Looking Radar: Coverage of The Geysers would cost roughly $\$ 1000$. 


\section{Further Suggestions}

- A data bank should be established in one central location. Sonoma State College is applying to the Department of Energy for a grant to do this project.

- Public workshops should be held for teachers, decision makers, and the general public. These would provide objective discussions of geothermal power at The Geysers-Calistoga KGRA. Sonoma State College has conducted such a workshop through the Department of Energy, and it has applied for a renewal grant for another workshop.

\section{Slope Stability and Geologic Hazards Group}

The group considered a number of possible hazards. For some of these, action was not judged appropriate. While well blowouts can be caused by the movement of earth materials during earthquakes, they are due principally to poor construction. No need was seen for a regional study. Abandoned mercury mines in the area pose hazards because of the presence of old tailings and the possibility of groundwater contamination. The locations of these mines are already known; however; they are shown on Robert McLaughlin's map and in a report to be published by Trinda Bedrossian. Renewed volcanism was discussed, but the probability of an eruption is very low.

The group noted the need for studies of several problems related to stability of earth materials, and it made the following four recommendations:

- The most critical requirement is a landslide map based on a good topographic map at a scale of $1: 12,000$. This would provide a regional map containing very valuable information. Although much mapping information is already available, it exists as a jumble of different scales, dates, and accuracies, spread out among numerous governmental and commercial organizations. The group believed that producing a new map would be less expensive than combining the existing data. Aerial photographic coverage at a scale of $1 \mathrm{in}$. $=500 \mathrm{ft}$ was recommended for slide areas in locations where future geothermal development is likely. The landslides should be classified according to age, stability, and type of movement. There was no clear consensus on who should do the mapping, but the group thought that private industry (consultants) could handle the work much more quickly than a government agency and that, as disinterested parties, they might be able to condense data from sensitive proprietary information more easily.
- An erosion map is needed. Erosion rates are closely linked to slides and weak soil areas. Detailed reports should accompany the map.

- An overall regional seismic study is needed because of the earthquake hazard. The existing USGS seismic net should be more closely spaced in the KGRA. Because stations are $10 \mathrm{~km}$ apart, it is difficult at present to determine epicenters accurately. Expected ground accelerations must be predictable. Pacific Gas and Electric Company claims that turbines cannot withstand high gravity loads.

- A centralized data bank is needed to store and disseminate all the information. The center might also update maps, collect pertinent environmental impact reports, and issue public announcements. Sonoma State College is a possible site. A computerized data bank under the USGS in Menlo Park is another possibility.

\section{Subsidence and Seismicity Group}

This group recommended a continuing research program to record events and surface changes as they occur with sufficient precision to develop a pattern that could be used to distinguish between natural and manmade changes and between changes in the geothermal production area and those in surrounding areas.

Most of the research and monitoring is being done by federal agencies, principally the USGS. The Corps of Engineers is studying the Maacama fault. Much of the microseismic and other geophysical work supported by industry is proprietary, and the information is not generally available. Existing studies already provide much of the needed baseline data. The following additional studies and research are recommended:

\section{Geodectic Monitoring (High-Priority Projects)}

- Expand the existing network to outside areas with a high potential for development (e.g., Wilbur Springs). An estimated 40 miles $(64 \mathrm{~km})$ would be needed. Cost: $\$ 18,000$.

- Establish several closely spaced, short lines for frequent precise resurveys to monitor for tilts and fault offsets. Cost: $\$ 10,000$.

- Establish guidelines, equipment, and reporting forms for collecting and reporting fluidproduction and reservoir data from industry. Cost: $\$ 6,000$.

\section{Geodectic Monitoring (Low-Priority Projects)}

- Install tiltmeters to monitor tilts and fault offsets. Cost: $\$ 20,000 / y r$. 
- Install extensometers to monitor changes in formations overlying the geothermal reservoir. No cost estimate.

\section{Seismicity}

Several important questions require answers:

- What is the relationship between earthquakes at the extended Geysers steam field and the production activities of the past, present, and future?

- What is the regional pattern of faulting, particularly in potential areas of development (e.g., Wilbur Springs) and in such major fault zones as the Maacama and Collayomi?

- How much shaking may be anticipated from local and regional earthquakes, and what is the ground response at different locations in the production area and adjacent areas?

To answer these questions, the group recommends, in order of priority:

- Continuing the existing dense network (approximately 3-km spacing) at The Geysers to study the possible relation between earthquakes and production and to map possible extensions of the zone of intense earthquake activity with expanded development. There are approximately eight stations. Cost: $\$ 100,000$.

- Establishing a network of digital seismographs (strong-motion event recorders) in the production area to determine ground response to shaking and provide data for source studies. Earthquakes as small as $m=2$ are routinely felt at The Geysers. About 12 stations are required, half of them permanently sited and half movable. Cost: $\$ 100,000$.

- Extending the sparse (approximately 3-km spacing) regional network to the north and east to provide details of regional activity, including Wilbur Springs and the Maacama fault as far north as Laytonville. Approximately 12 additional stations are required. Cost of instrumentation and operation: $\$ 100,000$. Cost of calibration explosions and interpretation: $\$ 50,000$.

- Establishing a roving network of portable seismographs (approximately eight) to provide detailed information on areas of interest within the regional network, fault-plane solutions, depth infor- mation, and a master event for relocation purposes. Cost: $\$ 100,000$.

- Making magnetic measurements. Cost: $\$ 50,000$.

- Making stress measurements from overcoring or hydrof racturing, using existing holes.

\section{Groundwater Hydrology Group}

The group's primary environmental concerns about groundwater were the overall degradation of the groundwater system, including reduction in the flow from hot and cold springs; lowering of groundwater piezometric surfaces; depletion of small groundwater subsystems; and reduction of groundwater quality.

The data needed for a comprehensive analysis of the ground-water systems at the KGRA are largely unavailable. The published data are almost exclusively from narrow, alluvium-filled valleys, and the information usually covers only a few years of well performance. The significant gaps in the available information preclude understanding the groundwater systems and subsystems. There is not enough information to understand how these systems respond even to natural phenomena, let alone to geothermal development. Thus, planners cannot make reasonable decisions governing proper geothermal development. To increase the understanding so that development can be controlled intelligently, the group recommends:

- Gathering water-quality data into a data bank, perhaps under the California Division of Water Resources.

- Conducting a canvass of hot and cold springs and wells, perhaps under the California Division of Water Resources.

- Studying the data and existing hydrologic/geologic investigations to provide an overall evaluation of the ground-water systems.

- Performing hydrologic studies of future geothermal development and of specific rock formations and/or aquifers.

- Using geothermal monitoring programs currently being developed.

- Establishing baseline monitoring programs for hot and cold springs and wells. 


\section{APPENDIX B: List of Workshop Attendees}

William Adams

U.S. Environmental Protection Agency

944 East Harmon Avenue

Las Vegas, NV 89109

Charles Armstrong

California Division of Mines and Geology

The Ferry Building

San Francisco, CA 94111

C. F. Bacon

California Division of Mines and Geology

2815 "O" Street

Sacramento, CA 95816

Trinda L. Bedrossian (Ristau)

California Division of Mines and Geology

Room 1004

The Ferry Building

San Francisco, CA 94111

Harold E. Beeston

California Energy Resource Conservation and

Development Commission

1111 Howe Avenue

Sacramento, CA 95825

Roald Bendixen

Bureau of Land Management

U.S. Department of the Interior

2800 Cottage Way

Sacramento, CA 95825

Charles Boardman

C. K. GeoEnergy

5030 Paradise Road

Las Vegas, NV 89119

Zene Bohrer

California Energy Resource Conservation and

Development Commission

1111 Howe Avenue

Sacramento, CA 95825

Tom Box

Aminoil USA, Inc.

P. O. Box 11279

Santa Rosa, CA 95406

Charles Bufe

U.S. Geological Survey

345 Middlefield Road

Menlo Park, CA 94025

R. Sue Caron

U.S. Department of Energy

1333 Broadway

Oakland, CA 94612

Marjorie Chan, L-224

Lawrence Livermore Laboratory

P. O. Box 808

Livermore, CA 94550

Rodger H. Chapman

California Division of Mines and Geology

2815 "O" Street

Sacramento, CA 95816
Ted Coffman

U.S. Army Corps of Engineers

211 Main Street

San Francisco, CA 94105

Neil B. Crow, L-212

Lawrence Livermore Laboratory

P. O. Box 808

Livermore, CA 94550

David R. Davis

Sonoma State College

Rohnert Park, CA 94928

Julie Donnelly

U.S. Geological Survey

345 Middlefield Road

Menlo Park, CA 94025

Jon A. Durham

U.S. Geological Survey

2465 East Bayshore Drive

Palo Alto, CA 95035

Michael Dwyer

Cooper Clark \& Associates

826 Grant Avenue

Novato, CA 94947

Rolfe Erickson

Geology Department

Sonoma State College

Rohnert Park, CA 94928

R. S. Ford

California Department of Water Resources

1416 9th Street

Sacramento, CA 95814

David Forsythe, Consultant

Seigler Springs Study

9180 Konocti Bay Road

Kelseyville, CA 95451

Bob Fujimoto

U.S. Geological Survey

345 Middlefield Road

Menlo Park, CA 94025

Doug Gall

Geothermal Resources

4676 Admiralty Way

Marina del Rey, CA 90291

Joy Gaskill

Sonoma State College

Rohnert Park, CA 94928

Fraser E. Goff

Rockwell Hanford Operations

Federal Building

Richland, WA 99352

Harold B. Goldman

Consulting Geologist

406 Marietta Drive

San Francisco, CA 94127 
J. Kew Is Ho

Pacific Gas and Electric Company

77 Beale Street

San Francisco, CA 94105

Fred Hoffman

U.S. Environmental Protection Agency

215 Fremont

San Francisco, CA 94105

William Holman

U.S. Geological Survey

345 Middlefield Road

Menlo Park, CA 94025

Louise Huen

California Public Utilities Commission

Fox Plaza Building

1390 Market Street

San Francisco, CA 94102

Betty K. Ishida, L-452

Lawrence Livermore Laboratory

P. O. Box 808

Livermore, CA 94550

Lynn Jones

State Lands Division

1807 13th Street

Sacramento, CA 95814

Paul Kasameyer, L-224

Lawrence Livermore Laboratory

P. O. Box 808

Livermore, CA 94550

Carroll F. Knutson

C. K. GeoEnergy

5030 Paradise Road

Las Vegas, NV 89119

Stephen R. Korbay

Harding-Lawson Associates

P.O. Box 3030

San Rafael, CA 94902

Gene Ledbetter, L-212

Lawrence Livermore Laboratory

P. O. Box 808

Livermore, CA 94550

Ben E. Lofgren

U.S. Geological Survey

Room 2528

2800 Cottage Way

Sacramento, CA 95825

Eric J. McHuron

Dames \& Moore

500 Sansome Street

San Francisco, CA 94111

Robert J. McLaughlin

U.S. Geological Survey

345 Middlefield Road

Menlo Park, CA 94025

Ronald Mearns

California Energy Research Conservation

and Development Commission

1111 Howe Avenue

Sacramento, CA 95825
H. J. Miller

California Division of Oil and Gas

1416 9th Street

Sacramento, CA 95814

Mary S. Moran

Oak Ridge National Laboratory

P. O. Box X

Bidg. 4500 N D-4

Oak Ridge, TN 37830

Kent S. Murray.

California Energy Resource Conservation

and Development Commission

1111 Howe Avenue

Sacramento, CA 95825

Nao Noguchi

Log B \& R International Consultants

The Ferry Building

San Francisco, CA 94111

Steve Norwick

Sonoma State College

Rohnert Park, CA 94928

Sue Noskar

Aminoil USA, Inc.

P. O. Box 11279

Santa Rosa, CA 95406

Richard E. Noster

Thermogenics, Inc.

2300 County Center Drive

Santa Rosa, CA 95401

John E. O'Rourke

Woodward Clyde Consultants

Room 700

Three Embarcadero Center

San Francisco, CA 94111

James M. Parsons

California Water Resources Control Board

P. O. Box 100

Sacramento, CA 95801

Larry Patzkowski

Pacific Gas and Electric Company

3400 Crow Canyon Road

San Ramon, CA 94583

John T. Phillips

Thermogenics, Inc.

2300 County Center Drive

Santa Rosa, CA 95401

Rick Prescott, Consultant

1023 Timothy Lane

Lafayette, CA 94549

Charles Priddy

State Lands Division

Suite 300

100 Oceangate

Long Beach, CA 90802

Roger W. Sherburne

California Division of Mines

and Geology

2815 "O" Street

Sacramento, CA 95816 
William P. Staub

Oak Ridge National Laboratory

P. O. Box X

Oak Ridge, TN 37830

Doug Stockton

California Division of Oil and Gas

1416 9th Street

Sacramento, CA 95814

Hilary Sullivan

U.S. Department of Energy

1333 Broadway

Oakland, CA 94612

Gary B. Taggart

Cooper-Clark \& Associates

826 Grant Avenue

Novato, CA 94947

Alan Tryhorn

Logistics International Consultants

218 World Trade Center

San Francisco, CA 94111

Terry Turner

Pacific Gas and Electric Company

3400 Crow Canyon Road

San Ramon, CA 94583

Mary Twichell

Aminoil USA, Inc.

P. O. Box 11279

Santa Rosa, CA 95406

James V. Vantine

Union Oil Company of California

Geothermal Division

5400 Santa Teresa

Santa Rosa, CA 95405
Dave Wagner

California Division of Mines and Geology

The Ferry Building

San Francisco, CA 94111

Mark A. Walters

Lake County Planning Department

255 North Forbes Street

Lakeport, CA 95453

Charles Wassinger

U.S. Geological Survey

District Geothermal Supervisor's Office

777 Sonoma Avenue

Santa Rosa, CA 95405

Charles Winterhalder

Harding-Lawson Associates

P. O. Box 3030

San Rafael, CA 94902.

Rodger Witham

U.S. Geological Survey

345 Middlefield Road, MS 92

Menlo Park, CA 94025

W. H. Wright III

Geology Department

Sonoma State College

Rohnert Park, CA 94928

Douglas M. Yadon

Earth Sciences Associates

701 Welch Road

Palo Alto, CA 94303

Richard Zipp

California Department of Water Resources 3251 "S" Street

Sacramento, CA 95816

RW 